\title{
Pediatric chronic osteomyelitis in the outskirts of Al-Ushbuna (Carnide, Lisboa, Portugal)
}

\author{
Ana Tavares $^{\mathrm{a}}$, Calil Makhoul ${ }^{\mathrm{b}}$, Mário Monteiro ${ }^{\mathrm{c}}$, Francisco Curate $\mathrm{F}^{\mathrm{b}, \mathrm{d}, \mathrm{e} \text {, * }}$ \\ ${ }^{a}$ Neonatal Functional Unit, Cascais Hospital - Dr. José de Almeida, Cascais, Portugal \\ b Centre for Functional Ecology, Laboratory of Forensic Anthropology, Department of Life Sciences, University of Coimbra, Coimbra, Portugal \\ ${ }^{\mathrm{c}}$ Emerita Arqueologia Lda., Oeiras, Portugal \\ d Research Centre for Anthropology and Health (CIAS), Department of Life Sciences, University of Coimbra, Coimbra, Portugal \\ ${ }^{\mathrm{e}}$ Interdisciplinary Center for Archaeology and Evolution of Human Behavior, University of Algarve, Faro, Portugal
}

\section{A R T I C L E I N F O}

Keywords:

Bone infection

Non-adults

Skeletal markers of stress

Medieval

Islamic period

\begin{abstract}
A B S T R A C T
The skeletal remains of seven individuals (five non-adults and two adults) were recovered during an archeological intervention in the township of Carnide (Lisbon, Portugal). Funerary anthropology strongly suggests that the sample is from the Medieval Islamic period (8th - 12th centuries AD). This report presents a case of chronic osteomyelitis in a non-adult individual. The diagnostic is substantiated by the presence of pathognomonic signs of osteomyelitis, including the presence of cloacae and a sequestrum in the left tibia. The bone infection is discussed in the context of inadequate socioeconomic conditions. This case from a relatively unfamiliar chronology and cultural context supplements the uncommon paleopathological descriptions of osteomyelitis in non-adults from historical populations.
\end{abstract}

\section{Introduction}

The history of osteomyelitis is ancient. The oldest evidence of an osteomyelitic infection was identified in the vertebral column of a Permian reptile (Moodie, 1923). Osteomyelitis of the scapula was recognized in the Shanidar 1 Neanderthal (Trinkaus and Zimmerman, 1982) and an association between bone infection and fracture was already suggested in the Hippocratic corpus. Notwithstanding, hematogenous osteomyelitis was described much later, in 1773 , by W. Bromfield (Klenerman, 2007). Osteomyelitis was a major health problem before antibiotics, with mortality rates up to $30 \%$ (Gilmour, 1962). After the introduction of penicillin mortality dropped to less than $1 \%$ (Dormans and Drummond, 1994).

Osteomyelitis is an inflammatory process of bone and bone marrow, usually caused by an infectious microorganism (Lew and Waldvogel, 2004; Macnicol and Watts, 2005). The major causative agent is Staphylococcus aureus, but other pathogens may be implicated, including Streptococcus spp., Haemophilus influenza type B, Kingella kingae, Salmonella spp., Pseudomonas aeruginosa, fungi (e.g., Aspergillus spp., Blastomyces dermatitidis), and multicellular parasites (Dormans and
Drummond, 1994; Lew and Waldvogel, 2004; Stone et al., 2016). Osteomyelitic infections can be restricted to a single area of the bone or affect several regions, e.g., the marrow, cortex, periosteum and soft tissues (Lew and Waldvogel, 2004; Macnicol and Watts, 2005).

The modern clinical classification of osteomyelitis is usually done by patient age (neonatal, childhood, adult), etiological agent, route of infection (exogenous or hematogenous) or clinical progress (Dormans and Drummond, 1994). Exogenous osteomyelitis results from local spread of a contiguous infected source (e.g., cellulitis), and trauma, including bone surgery/prosthetic replacement. It can also be secondary to vascular insufficiency, especially in patients with diabetes (Lew and Waldvogel, 2004). Hematogenous osteomyelitis is characterized by bacterial seeding from the endosteal blood supply; it is common in prepubertal children and older individuals (Harik and Smeltzer, 2010; Lew and Waldvogel, 2004). Clinical presentation can be acute, subacute or chronic (Macnicol and Watts, 2005). Acute osteomyelitis progresses for days or weeks, and typically occurs in the metaphysis of long bones, in most cases as a single focus in the femur or tibia (Dormans and Drummond, 1994). Chronic osteomyelitis is defined - rather subjectively - when it develops for months or even years, being typified by low intensity inflammation, and the presence of necrotic bone and fistulae (Dormans and Drummond, 1994; Harik and Smeltzer, 2010).

\footnotetext{
* Corresponding author at: Research Centre for Anthropology and Health (CIAS), Department of Life Sciences, University of Coimbra, Coimbra, Portugal.

Email address: fcurate@uc.pt, franciscocurate@gmail.com (F. Curate)
} 
In the past, osteomyelitis was highly prevalent in children (e.g., Amberg and Ghormley, 1934; Homans, 1912; Nichols, 1904; Wade, 1929; Wakeley, 1932). Curiously, the diagnosis of osteomyelitis in archeological contexts is relatively uncommon, particularly pediatric osteomyelitis, with few cases reported in the paleopathological literature (Ortner, 2003; Flensborg et al., 2013; Lewis, 2007; Santos and Suby, 2015; Table 1). Accordingly, the purpose of this paper is to present a case of pediatric chronic osteomyelitis in the tibia from an indi- vidual recovered in a Medieval Islamic site in the environs of Al-Ushbuna (Portugal).

\section{Case study}

\subsection{Archeological background}

During an archeological monitoring at a construction site in the township of Carnide (Lisbon, Portugal), the skeletal remains of seven

Table 1

Pediatric osteomyelitis in the paleopathological literature.

\begin{tabular}{|c|c|c|c|c|c|}
\hline Source & Archeological site & $\begin{array}{l}\text { Chronological } \\
\text { period }\end{array}$ & Age & $\begin{array}{l}\text { Route of } \\
\text { infection }\end{array}$ & Skeletal site \\
\hline Lax et al. (1982) & Dor, Israel & 7th century $\mathrm{AD}$ & 8 years & $\begin{array}{l}\text { Exogenous, } \\
\text { fracture }\end{array}$ & Right ulna, other long bones \\
\hline Canci et al. (1991) & Toppo Daguzzo, Italy & Bronze Age & 5 years & Hematogenous & $\begin{array}{l}\text { Left fibula, other long bones, } \\
\text { scapula }\end{array}$ \\
\hline Sheth et al. (1994) & Mexico & $\begin{array}{l}\text { Possibly pre- } \\
\text { Columbian }\end{array}$ & Child & - & Right tibia \\
\hline Sheth et al. (1994) & Alaska, USA & $\begin{array}{l}\text { Possibly pre- } \\
\text { Columbian }\end{array}$ & Adolescent & - & Left tibia \\
\hline Ubelaker and Pap (1998) & Tápiószele, Hungary & Iron Age & 10-11 years & - & Left fibula, other long bones \\
\hline Baxarias (1999) & $\begin{array}{l}\text { Prat de la Riba, Tarragona, } \\
\text { Spain }\end{array}$ & Late Roman & $\begin{array}{l}12-14 \\
\text { years }\end{array}$ & Hematogenous & $\begin{array}{l}\text { Right tibia, long bones, } \\
\text { vertebrae }\end{array}$ \\
\hline Ortner (2003) & La Oroya, Peru & $\begin{array}{l}\text { Possibly pre- } \\
\text { Columbian }\end{array}$ & 9 years & Hematogenous & Left tibia \\
\hline Ortner (2003) & $\begin{array}{l}\text { Montgomery County, MD, } \\
\text { USA }\end{array}$ & $1200-1300 \mathrm{CE}$ & 6 years & $\begin{array}{l}\text { Exogenous, } \\
\text { fracture }\end{array}$ & Left and right tibiae \\
\hline Lewis (2007) & Eccles, Kent, UK & $\begin{array}{l}\text { 6th }-8 \text { th centuries } \\
\mathrm{AD}\end{array}$ & Adolescent & - & Right tibia \\
\hline $\begin{array}{l}\text { Rohnbogner and Lewis } \\
\text { (2016) }\end{array}$ & Trentholme Drive, York, UK & $\begin{array}{l}\text { 3rd }-4 \text { th centuries } \\
\mathrm{AD}\end{array}$ & $\begin{array}{l}6.6-10.5 \\
\text { years }\end{array}$ & $\begin{array}{l}\text { Possibly TB } \\
\text { related }\end{array}$ & Right fibula, other bones \\
\hline
\end{tabular}

Table 2

Paleodemographic, funerary and paleopathological data (Palácio de Sant'Ana).

\begin{tabular}{|c|c|c|c|c|c|c|c|c|}
\hline Individual & $\begin{array}{l}\text { Age } \\
\text { class }\end{array}$ & Skeletal age & Dental age & Sex & Burial type & Orientation & $\begin{array}{l}\text { Skeletal } \\
\text { position }\end{array}$ & Pathology \\
\hline$\# 1$ & $\begin{array}{l}\text { Non- } \\
\text { adult }\end{array}$ & $\begin{array}{l}9.0-11.0 \\
\text { years }\end{array}$ & $\begin{array}{l}11.0-13.5 \\
\text { years }\end{array}$ & Indeterminate & Shallow grave & SW - NE & $\begin{array}{l}\text { Right lateral } \\
\text { decubitus }\end{array}$ & $\begin{array}{l}\text { LEH, } \\
\text { osteomyelitis }\end{array}$ \\
\hline$\# 2$ & $\begin{array}{l}\text { Non- } \\
\text { adult }\end{array}$ & $\begin{array}{l}6.0-7.5 \\
\text { years }\end{array}$ & $7-9$ years & Indeterminate & $\begin{array}{l}\text { Delimited by } \\
\text { stones }\end{array}$ & SW - NE & $\begin{array}{l}\text { Right lateral } \\
\text { decubitus }\end{array}$ & $\begin{array}{l}\text { Cribra } \\
\text { orbitalia }\end{array}$ \\
\hline \#3 & $\begin{array}{l}\text { Non- } \\
\text { adult }\end{array}$ & $\begin{array}{l}0.5-1.0 \\
\text { years }\end{array}$ & $\begin{array}{l}1.5-2.0 \\
\text { years }\end{array}$ & Indeterminate & Shallow grave & SW - NE & $\begin{array}{l}\text { Right lateral } \\
\text { decubitus }\end{array}$ & - \\
\hline \#4 & $\begin{array}{l}\text { Non- } \\
\text { adult }\end{array}$ & $\begin{array}{l}1.0-2.0 \\
\text { years }\end{array}$ & & Indeterminate & Shallow grave & SW - NE & $\begin{array}{l}\text { Right lateral } \\
\text { decubitus }\end{array}$ & - \\
\hline \#5 & $\begin{array}{l}\text { Non- } \\
\text { adult }\end{array}$ & $\begin{array}{l}0.5-1.0 \\
\text { years }\end{array}$ & & Indeterminate & Shallow grave & SW - NE & $\begin{array}{l}\text { Right lateral } \\
\text { decubitus }\end{array}$ & $\begin{array}{l}\text { Porotic } \\
\text { hyperostosis }\end{array}$ \\
\hline \#6 & $\begin{array}{l}20-29 \\
\text { years }\end{array}$ & & & Male & Shallow grave & SW - NE & $\begin{array}{l}\text { Right lateral } \\
\text { decubitus }\end{array}$ & LEH, calculus \\
\hline \#7 & Adult & & & Female & Shallow grave & $\mathrm{SW}-\mathrm{NE}$ & $\begin{array}{l}\text { Right lateral } \\
\text { decubitus }\end{array}$ & - \\
\hline
\end{tabular}

LEH: Linear enamel hypoplasia.

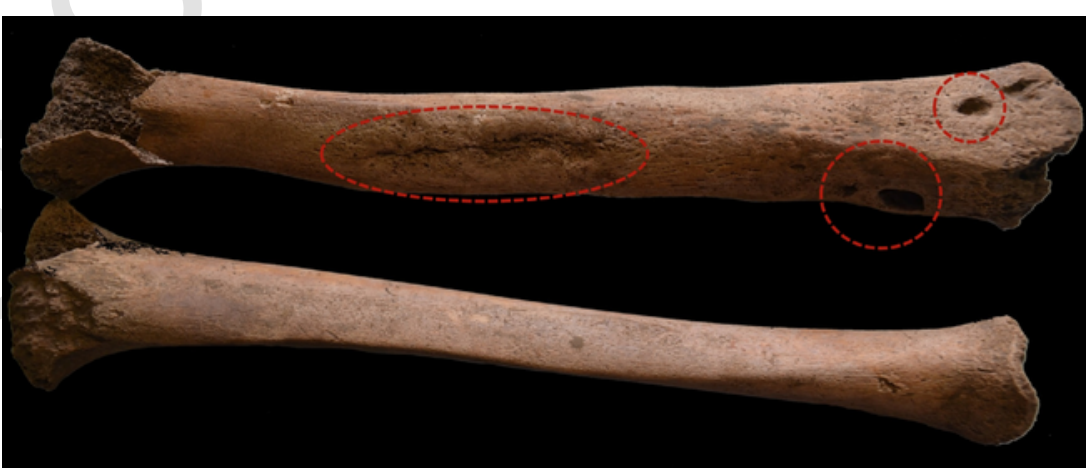

Fig. 1. Left and right tibias of individual \#1; diaphyseal expansion in the left tibia, with cloacae in the distal region. 


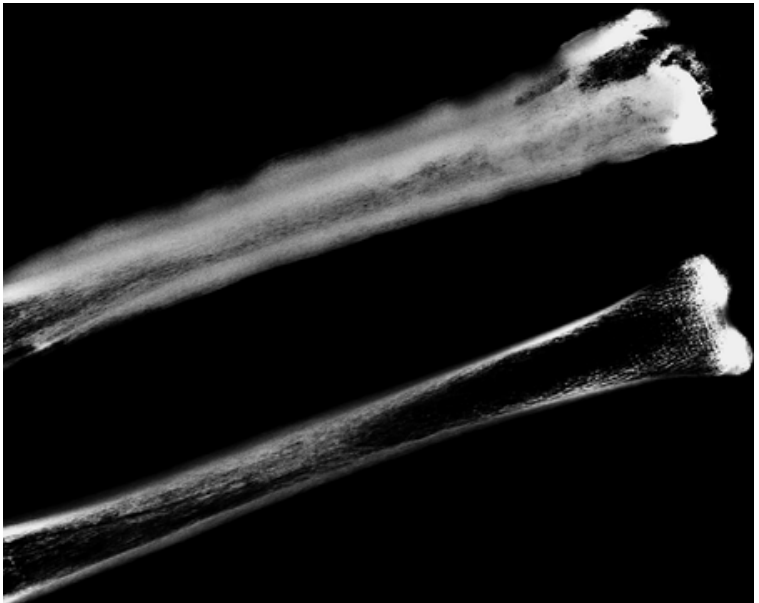

Fig. 2. Plain radiographs of the left and right tibias of individual \#1.

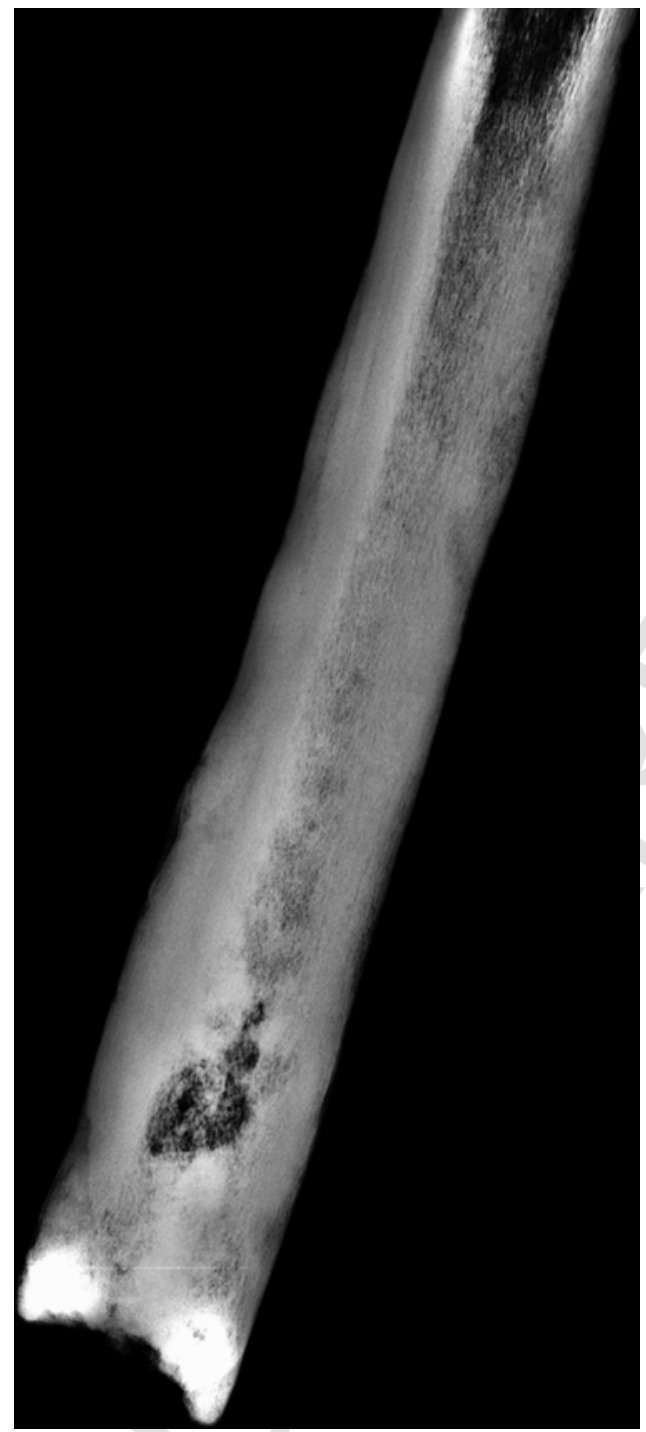

Fig. 3. Plain radiograph of the left tibia of individual \#1; notice the large cloaca and $s e$ questrum.

individuals were recovered, including five non-adults (Table 2). Age at death of the non-adults was estimated through skeletal and dental development (AlQahtani et al., 2010; Maresh, 1970). They were buried in

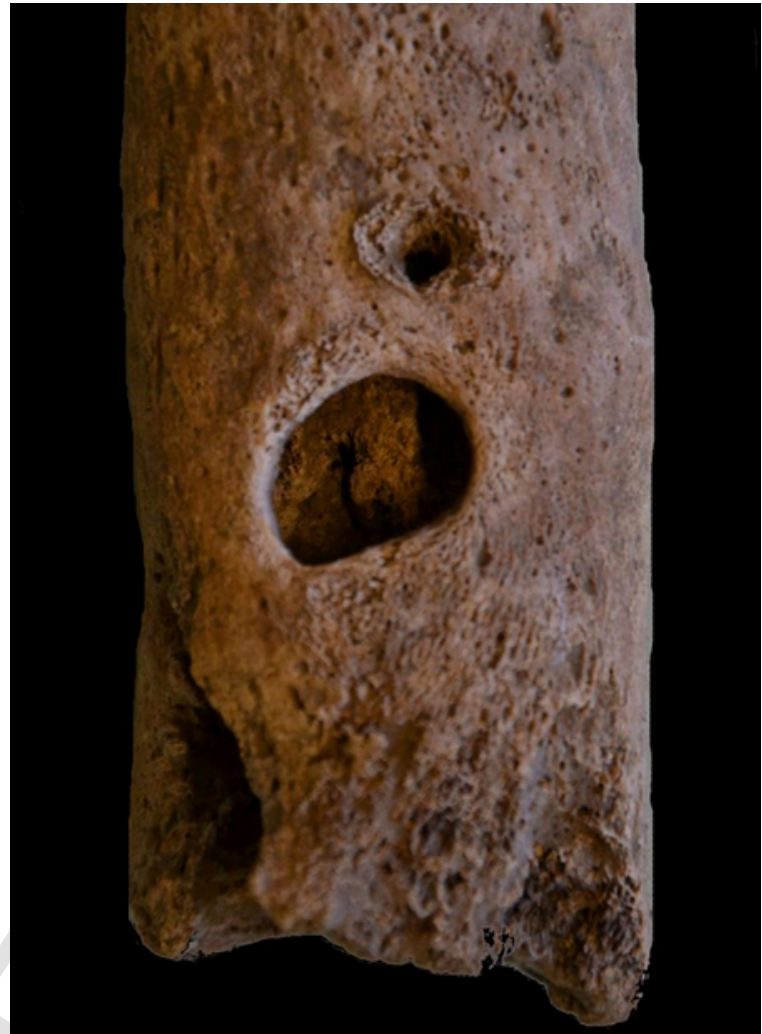

Fig. 4. Detail of the sequestrum in the larger cloaca.

the necropolis of an al-garya (rural villages around bigger cities) from the Medieval Islamic period (8th - 12th centuries AD) in the outskirts of Lisbon. Lisbon was conquered in $714 \mathrm{CE}$ by the troops of Abdelaziz ibn Musa, and then renamed Al-Ushbuna. In 1147 CE, Christian crusaders commanded by Afonso I seized the city and its environs, including Carnide (Santos, 2015). Burial mode and typology is in accordance with Islamic funerary ritual, as archeologically documented in the Al-Andalus (Iberian Peninsula): absence of votive artifacts, shallow and unmarked graves with a SW - NW orientation, which assured a perpendicular alignment with the Qibla (i.e., Mecca), and bodies placed in right lateral decubitus with the face towards Mecca. The focus of this case study is a non-adult that presented osteomyelitis in the left tibia.

\section{Individual \# 1}

Individual \#1, an almost complete and well-preserved skeleton, died between 9.0-11.0 years (Maresh, 1970) and 11.0-13.5 years (AlQahtani et al., 2010). The right tibia of this individual displayed an active lesion of periosteal new bone formation, located in the mid-diaphyseal posterior region. In the left tibia, it was observed an anomalous thickening of the distal diaphysis and metaphysis, with the involucrum surrounding an area of devascularized dead bone (sequestrum), and periosteal new bone formation. Diaphyseal expansion attains maximum perimeter in the distal region at $12.9 \mathrm{~mm}$. Maximum circumference at mid-diaphysis is $9.4 \mathrm{~mm}$ (as opposed to $7.0 \mathrm{~mm}$ in the same area of the right tibia). Three cloacae were identified (Figs. 1-3) in the distal metaphyseal-diaphyseal area. Two of the cloacae, in medial location, perforated the diaphysis. The largest $(15.7 \times 12.3 \mathrm{~mm})$ exhibited a well remodeled, regular, border. The sequestrum - necrotic bone of irregular morphology - is easily discernible inside the cloaca (Fig. 4). The smaller cloaca $(4.4 \times 3.5 \mathrm{~mm})$ is located above the larger (distance of $6.5 \mathrm{~mm}$ ). Both orifices are part of a single canal that contains the sequestrum. Macroscopical analysis of the skeleton and plain radiographies of both tibiae showed no evidence of trauma. All the recovered 
mandibular teeth presented at least one linear enamel hypoplasia (LEH). No other pathologies were observed in this individual. Other individuals in the sample presented non-specific indicators of stress, including cribra orbitalia and porotic hyperostosis (see Table 2).

\section{Discussion}

The presence of cloacae and sequestra with periosteal new bone formation are pathognomonic of chronic osteomyelitis (Ortner, 2003; Santos and Suby, 2015; Sheth et al., 1994). The cloaca is an opening in a involucrum that enables drainage of purulent and necrotic matter from the dead bone (Macnicol and Watts, 2005). The case described represents, according to the Penny (2004) anatomical classification, a «typical» type I osteomyelitis, with a well-defined sequestrum and involucrum. The tibia and femur are the skeletal elements more often involved (Dormans and Drummond, 1994; Lew and Waldvogel, 2004) and, in the majority of cases, the lesion is solitary although it can be multifocal, especially in neonates (Yeo and Ramachandran, 2014). In the few paleopathological cases of pediatric chronic osteomyelitis, the involvement of different bones seems to be the rule, with a slight preponderance of the tibia (see Table 1). A study of pediatric acute hematogenous osteomyelitis in the Coimbra Identified Skeletal Collection (and the Coimbra University Hospital records) suggests that the lower limb bones were the most affected in pre-antibiotic populations (Santos and Suby, 2015; see also Amberg and Ghormley, 1934; Homans, 1912; Nichols, 1904).

There are no signs of trauma in the studied juvenile, but an exogenous origin of osteomyelitis cannot be definitely discarded. A diagnosis of hematogenous osteomyelitis is more plausible. Pediatric hematogenous osteomyelitis commonly involves the long bones of the leg, with a single focus, and presents a bimodal distribution, usually affecting infants with less than two years and preadolescents between eight and twelve years (Stone et al., 2016; Yeo and Ramachandran, 2014). It is more common in individuals with compromised immunity, chronic disease, concomitant infectious diseases (parasites, Mycobacteria), anemia, malnutrition and substandard sanitary conditions (Macnicol and Watts, 2005; Spiegel and Penny, 2005). The profile of the studied individual is consistent with these demographic and socioecological characteristics. The child was buried in the funerary ground of a small al-garya - Carnide - in the outskirts of Al-Ushbuna. The periphery of Lisbon was characterized by an agrarian subsistence model (Santos, 2015). Bioarcheological data pertaining this small sample point to faulty socioeconomic conditions - most of the studied non-adult individuals experienced physiological systemic stress. Also, the observed differences between dental and skeletal development suggest a lower than average environmental quality (Cardoso, 2007).

The complications associated with non-adult chronic osteomyelitis include the suppression of the growth plate with skeletal deformity, pathological fractures, avascular necrosis, cachexia, septicemia, and death (Macnicol and Watts, 2005; Tudisco et al., 1991). It was not possible to ascertain the cause of death of the studied preadolescent; notwithstanding, the diagnosis of osteomyelitis, as the presence of LEH, discrepancy in skeletal and dental maturation, and age at death, are suggestive of overall frailty. In other paleopathological examples (e.g., Baxarias, 1999; Canci et al., 1991) the association of osteomyelitis with other skeletal markers of stress is interpreted in a global context of sanitary and nutritional deficits. Medical knowledge in the Medieval Islamic world was prolific (Lawrence, 2009) but in this case there are no signs of therapeutic intervention of any type (see, e.g., Binder et al., 2016; Mitchell, 1999; Toyne, 2015).

Osteomyelitis in the past was very common, especially in prepubertal children. Notwithstanding, most paleopathological cases were observed in adults, with only a few cases affecting non-adults. Frequently, pediatric osteomyelitis does not produce pathognomonic lesions; as such, the identification of osteomyelitis in past populations, especially in non-adults, is intricate (Ortner, 2003; Santos and Suby, 2015). This case from a Medieval Islamic site in the Al-Andalus, a relatively unfamiliar chronology, geography and cultural context, complements the limited case histories of osteomyelitis in non-adults from past populations.

\section{Acknowledgments}

The authors wish to acknowledge the Portuguese Science and Technology Foundation (FCT, grant number \# SFRH/BPD/74015/ 2010), and the editor and anonymous reviewers for the thoughtful corrections and remarks.

\section{References}

AlQahtani, S.J., Hector, M.P., Liversidge, H.M., 2010. The London atlas of human tooth development and eruption. Am. J. Phys. Anthropol. 142, 481-490.

Amberg, S., Ghormley, R., 1934. Osteomyelitis among children. J. Pediatr. 5, 177-193.

Baxarias, J., 1999. Estudio paleopatológico de um caso de osteomielitis con espondilitis cervicodorsal de la necrópolis tardorromana de Prat de la Riba (Tarragona). In: Macias, M.M., Picazo, J.E. (Eds.), La Enfermedad En Los Restos Humanos Arqueológicos. Ayuntamiento de San Fernando y Universidad de Cádiz, San Fernando, pp. 399-405.

Binder, M., Eitler, J., Deutschmann, J., Ladstätter, S., Glaser, F., Fiedler, D., 2016. Prosthetics in antiquity: an early Medieval wearer of a foot prosthesis from Hemmaberg. Aust. Int. J. Paleopathol. 12, 29-40.

Canci, A., Tarli, S.M.B., Repetto, E., 1991. Osteomyelitis of probable haematogenous origin in a bronze age child from toppo daguzzo (Basilicata, southern Italy). Int. J. Osteoarchaeol. 1, 135-139.

Cardoso, H., 2007. Environmental effects on skeletal versus dental development: using a documented subadult skeletal sample to test a basic assumption in human osteological research. Am. J. Phys. Anthropol. 132, 223-233.

Dormans, J.P., Drummond, D.S., 1994. Pediatric hematogenous osteomyelitis: new trends in presentation, diagnosis, and treatment. J. Am. Acad. Orthop. Surg. 2, 333-341.

Flensborg, G., Suby, J.A., Martínez, G., 2013. A case of adult osteomyelitis in a final late holocene hunter-gatherer population eastern Pampa-Patagonian transition. Argent. Int. J. Paleopathol. 3, 128-133.

Gilmour, W.N., 1962. Acute haematogenous osteomyelitis. J. Bone Joint. Surg. Br. 44 841-853.

Harik, N.S., Smeltzer, M.S., 2010. Management of acute hematogenous osteomyelitis in children. Expert Rev. Anti Infect. Ther. 8, 175-181.

Homans, J., 1912. Osteomyelitis of the long bones: a study of ninety-four cases from the Children's Hospital. Boston.Ann. Surg. 55, 375-387.

Klenerman, L., 2007. A history of osteomyelitis from the Journal of Bone and Joint Surgery: 1948-2006. J. Bone Joint Surg. Br. 89, 667-670.

Lawrence, C.I., 2009. The arab-Islamic medical tradition. In: Lawrence, C.I. (Ed.), The Western Medical Tradition: 800 to 1800 CE.. Cambridge University Press, Cambridge, pp. 93-138.

Lax, E., Perez, B., Smith, P., 1982. The roentgenologic diagnosis of osteomyelitis in skeletal remains. Ossa 8, 147-155.

Lew, D.P., Waldvogel, F.A., 2004. Osteomyelitis. Lancet 364, 369-379.

Lewis, M., 2007. The Bioarchaeology of Children: Perspectives from Biological and Forensic Anthropology. Cambridge University Press, Cambridge.

Macnicol, M.F., Watts, A.C., 2005. Haematogenous osteomyelitis. Surgery 23, 25-30.

Maresh, M.M., 1970. Measurements from roentgenograms, heart size, long bone lengths, bone, muscle and fat widths, skeletal maturation. In: McCammon, R.W. (Ed.), Human Growth and Development. Charles C. Thomas, Springfield, pp. 155-200.

Mitchell, P.D., 1999. The integration of the palaeopathology and medical history of the Crusades. Int. J. Osteoarchaeol. 343, 333-343.

Moodie, R.L., 1923. Paleopathology: an Introduction to the Ancient Evidences of Disease. University of Illinois Press, Illinois.

Nichols, E.H., 1904. Acute, subacute and chronic infectious osteomyelitis: its pathology and treatment. JAMA XLII (7), 439-466.

Ortner, D.J., 2003. Identification of Pathological Conditions in Human Skeletal Remains. Elsevier Science/Academic Press, New York.

Penny, J.N., 2004. Children's orthopaedic surgery and rehabilitation in Africa. AAOS ICL 228.

Rohnbogner, A., Lewis, M.E., 2016. Poundbury Camp in context - a new perspective on the lives of children from urban and rural Roman England. Am. J. Phys. Anthropol 208-228.

Santos, A.L., Suby, J.A., 2015. Skeletal and surgical evidence for acute osteomyelitis in non-adult individuals. Int. J. Osteoarchaeol. 25, 110-118.

Santos, F., 2015. Território e povoamento no termo de Lisboa entre o período muçulmano e 1321. In: Faria, D., Lopes, F. (Eds.), Incipit 3. Workshop de Estudos Medievais da Universidade do Porto 2013-2014.. Universidade do Porto, Faculdade de Letras Biblioteca Digital. pp. 17-21.

Sheth, P.A., Sartoris, D.J., Resnick, D., Tyson, R., Haghighi, P., 1994. An analysis of chronic osteomyelitis of the tibia in a pre-Columbian human population using radiographic-pathological correlation. Int. J. Osteoarchaeol. 4, 3-12.

Spiegel, D.A., Penny, J.N., 2005. Chronic osteomyelitis in children. Tech. Orthop. 20, $142-152$.

Stone, B., Street, M., Leigh, W., Crawford, H., 2016. Pediatric tibial osteomyelitis. J. Pediatr. Orthop. 36, 534-540. 
Toyne, J.M., 2015. Tibial surgery in ancient Peru. Int. J. Paleopathol. 8, 29-35.

Trinkaus, E., Zimmerman, M., 1982. Trauma among the shanidar neandertals. Am. J. Phys. Anthropol. 76, 61-76.

Tudisco, C., Farsetti, P., Gatti, S., Ippolito, E., 1991. Influence of chronic osteomyelitis on skeletal growth: analysis at maturity of 26 cases affected during childhood. J. Pediatr. Orthop. 11, 358-363.
Ubelaker, D.H., Pap, I., 1998. Skeletal evidence for health and disease in the Iron Age of Northeastern Hungary. Int. J. Osteoarchaeol. 8, 231-251.

Wade, R.B., 1929. Acute osteomyelitis. in children. Med. J. Aust I 264

Wakeley, C.P.G., 1932. Acute osteomyelitis in children. BMJ ii, 752

Yeo, A., Ramachandran, M., 2014. Acute haematogenous osteomyelitis in children. BMJ $348,66-74$. 